\title{
Belajar Di Rumah Solusi Belajar Di Era Pandemi Covid-19
}

\author{
Taqiyuddin \\ IAIN Syekh Nurjati Cirebon \\ e-mail: htaqiyuddin@gmail.com
}

\begin{abstract}
ABSTRAK
Tujuan kegiatan pengabdian ini adalah untuk memberdayakan masyarakat melalui pembinaan dan pendampingan anak-anak sekolah di desa Astapada. Dalam melakukan pendampingan pembelajaran dari rumah dengan tetap menerapkan protokol kesehatan, penulis menggunakan metode Belajar Bersama di rumah belajar, yaitu pembelajaran dengan berkelompok anak. Metode ini dipilih karena dengan melakukan kegiatan belajar bersama anak lebih mudah memahami apa yang akan dilakukan untuk tugasnya bersama dengan teman-temannya. Dalam melakukan evaluasi hasil dari pendampingan pembelajaran, penulis menggunakan metode observasi atau wawancara langsung denban masyarakat terutama anak-anak usia sekoilah yang mengikuti belajar bersama di rumah belajar. Berdasarkan Hasil dari pengabdian dalam bidang pendidikan adalah 1) Mendapatkan banyak dukungan dari warga maupun pihak desa tentang adanya pengadaan sarana belajar selama pandemi ini. 2) Banyak anak-anak yang menghabiskan waktunya untuk belajar bersama dibandingkan dengan bermain, 3) Anak-anak dapat mengelola barang bekas seperti plastik menjadi bahan yang lebih bermanfaat. 4) Anak-anak dapat menambah rasa percaya diri dengan berani menceritakan pengalamannya di depan temantemannya.
\end{abstract}

Kata kunci: Belajar di Rumah; Pandemi Covid-19

\begin{abstract}
The purpose of this service activity is to empower the community through coaching and mentoring school children in Astapada village. In conducting learning assistance from home while still implementing health protocols, the authors use the Collaborative Learning method of at-home learning, namely learning with groups of children. This method was chosen because by doing learning activities with children it is easier to understand what will be done for their assignments together with their friends. In evaluating the results of learning assistance, the author uses the method of observation or direct interviews with the community, especially children of school age who participate in learning together in the learning house. Based on the results of community service in the field of education, 1) Get a lot of support from residents and villages regarding the provision of learning facilities during this pandemic. 2) Many children spend their time learning together rather than playing, 3) Children can manage used items such as plastics to become more useful materials. 4) Children can increase their self-confidence by courageously telling their experiences in front of their friends.
\end{abstract}

Keywords: Study at Home; The Covid-19 Pandemic 


\section{PENDAHULUAN}

Pendidikan dapat diartikan sebagai suatu proses transformasi ilmu pengetahuan, keterampilan, pengalaman dan kebiasaan seseorang kepada orang lain melalui pembelajaran, pembinaan, pembimbingan dan/atau pelatihan. Proses kependidikan sering terjadi karena adanya interaksi antar individu atau antara individu dengan masyarakat, tetapi ada juga ada yang melakukannya secara otodidak (belajar mandiri, tanpa pembimbingan) (Arsyad, 2011).

Upaya Pemerintah melalui UU RI no 20 tahun 2003 tentang Sistem Pendidikan Nasional menggambarkan bahwa pendidikan diwajibkan bagi semua bangsa (Education for All), tidak pula membatasi akses peserta didik kependidikan (Herawati, 2010), baik pendidikan itu diselenggarakan oleh lembaga-lembaga pendidikan sekolah/Madrasah atau non-sekolah. Bahkan pendidikan dengan model tertentu hadir di rumah perorangan/masyarakat, dalam betuk sistem home-schooling, atau pembelajaeran dalam bentuk e-learning yang dapat mengubah keterbatasan waktu, jarak dan biaya menjadi sebuah peluang dalam memudahkan proses pembelajaran (Winarno \& Setiawan, 2013). Hal ini menunjukkan urgensi pentingnya pendidikan sebagai salah satu aspek dalam membangun bangsa yang maju, handal, profesional dan berdaya saing. Sebagaimana yang dijelaskan dalam (Vito, et al. 2015) bahwa untuk memenuhi tujuan terciptanya sumber daya manusia yang berkualitas tentunya pendidikan adalah faktor terpenting yang tidak dapat dipisahkan, karena dapat secara efektif mambangun bangsa yang berkarakter (nation and character building).

Lahirnya Covid-19 yang penamaannya disematkan World Health Organization (WHO) (Sarip, et al, 2020) atas coronavirus disease yang terkonfirmasi pada tahun 2019, dengan sebutan Covid-19. Memiliki dampak yang luar biasa terhadap seluruh sektor di Indonesia tak terkecuali sektor pendidikan. Dampak dari adanya pandemi tersebut adalah kebijakan Pemerintah yang menganjurkan agar masyarakat tetap tinggal dirumah sehingga menimbulkan perubahan dalm kehidupan sehari-hari (Dani, et al., 2021). Dengan kalimat lain, masa pandemi Covid-19 membuat pola pendidikan di Indonesia berubah sehingga memberikan tantangan tersendiri bagi lembaga pendidikan di Indonesia. Sebagaimana yang dijelaskan dalam (Annisa, 2021), dengan adanya pandemi, pemerintah memutuskan untuk melakukan penutupan pada beberapa sekolah dan perguruan tinggi sehingga pembelajaran yang biasanya dilakukan secara tatap muka (konvensional), sistemnya berubah menjadi pembelajaran dirumah yang dilakukan secara jarak jauh dan menggunakan media online (Arizona, et, al., 2020).

Perubahan pola pendidikan atau Kegiatan Belajar Mengajar (KBM) berimbas kepada system pembelajaran yang dilakukan oleh tenaga pendidik (guru) yaitu yang pada awalnya diliburkan selama dua minggu, kemudian menjadi Work from Home (WfH) selama waktu yang 
belum bisa ditentukan. Hal ini mengakibatkan seluruh sekolah di Indonesia melakukan pembelajaran di rumah. Perubaahan pola KBM juga berimbas kepada sikap mental masyarakat (terutama di daerah-daerah terpencil) yang tidak memiliki perangkat yang memenuhi syarat kelayakan bagi pelaksanaan KBM jarak jauh.

Dampak lainnya, fasilitas jaringan internet yang menjamin keterhubungan pun belum merata keberadaannya di seluruh pelosok Tanah Air. Kesulitan nonteknis berkaitan dengan kondisi Pandemi Covid-19 adalah tidak semua guru dan murid dapat segera beradaptasi dengan teknologi dalam menggunakan metode Pembelajaran belajar Jarak Jauh (PJJ). Penguasaan siswa ataupun guru terhadap teknologi pembelajaran juga sangat bervariasi. Hal lain yang tidak kalah seriusnya yaitu kurukulum pendidikan nasional secara resmi belum mengakomodasi dan mengadaptasi sistem PJJ. Selain beberapa permasalahan dalam pendidikan kepada masyarakat (learning societ), kemampuan akademik orang tua juga ikut menjadi kendala dalam membimbing belajar anak-anaknya.

Beberapa kondisi diatas secara tidak langsung menggambarkan kondisi sistem pendidikan yang terpaksa harus berubah dari kegiatan belajar mengajar yang tadinya dilaksanakan dengan tatap muka dan didampingi oleh guru akhirnya harus menggunakan sistem belajar di rumah dengan memanfaatkan media daring (online) seperti WhatsApp, Classroom dan lain sebagainya. Sebagian beesar masyarakat pada saat ini bertanggung jawab mendampingi anak-anak belajar dari rumah. Hal ini tentu saja menjadikan adanya pergeseran metode pembelajaran yang mendadak sehingga dinilai tidak terlalu efektif dan optimal (Majid, et al., 2021) karena para guru maupun siswa tidak mampu beradaptasi secara cepat (Majid, 2013), (Putri, 2021) seiring dengan perkembangan kebutuhan pemenuhan pendidikan di era pandemi covid-19.

Desa Astapada adalah salah satu desa yang berada di Kecamatan Tengah tani Kabupaten Cirebon. Mayoritas penduduk Astapada merupakan penduduk asli, dan sebagian saja masyarakat Astapada yang merupakan pendatang/pindahgan lantaran di desa Astapada ada kompleks Perumahan. Masyarakat Astapada sudah berada pada tingkat yang cukup baik. Meskipun belum banyak masyarakatnya yang menempuh jenjang pendidikannya ke jenjang perguruan tinggi, namun minat masyarakat terhadap pendidikan baik pendidikan non formal dan formal sudah lebih dari cukup. Salah satu contohnya adalah masih banyaknya anak-anak yang aktif dalam kegiatan Madrasah atau sekedar mengikuti kegiatan Majelis Ta'lim setelah mengikuti sekolah formal setiap sorenya. Anak-anak di desa Astapada pada umumnya memiliki minat yang tinggi dalam belajar namun tidak disertai dengan pendamping yang dapat menunjang minat mereka.

Berdasarkan hasil survei dan observasi awal terhadap masyarakat Desa Astapada, diperoleh informasi bahwa dalam Bidang pendidikan/pembelajaran msyarakat Astapada masih 
banyak yang kurang kemampuan akademiknya dalam membimbing dan mendampingi anakanaknya saat bekajar. Hal ini karena banyak orang tua yang tidak bisa membimbing anak-anaknya, tetapi di sisi lain banyak orangtua yang memiliki antusiasme yang tinggi dalam mendorong anakanaknya dalam belajar. Salah satu bentuk antusiasme para orang tua adalah dengan adanya usulan kegiatan pembelajaran di masa pandemi Covid-19 ini. Menurutnya, hal ini akan sangat membantu untuk mendukung pemenuhan hak anak-anak untuk tetap belajar dengan baik meskipun hanya dilakukan di rumah dan dengan fasilitas penunjang kegiatan belajar yang terbatas.

Berdasarkan latar belakang tersebut, penulis merasa perlu untuk berbagi pengalaman dan keterampilan sebagai bentuk kepedulian terhadap pendidikan masyarakat Indonesia utamanya masyarakat di Desa Astapada Kecamatan Tengahtani Kabupaten Cirebon mengusung tema Masyarakat Belajar di Rumah Belajar Era Pandemi Covid 19.

\section{BAHAN DAN METODE}

Kegiatan pengabdian ini dilakukan di Desa Kecamatan Tengah Tani, Kabupaten Cirebon. Pelaksanaan pengabdian ini menggunakan pendekatan partisipatif dan kualitatif, yakni pendekatan yang dilakukan dengan melibatkan masyarakat untuk kemudian dilakukan pengumpulan data dan diolah menjadi sebuah deskripsi ataupun narasi (Layaman, et al., 2020). Pendekatan ini dapat juga disebut sebagai pendekatan penelitian deksriptif kualitatif, yang mana menurut Indrawan dalam (Bakhri, et al., 2020) bertujuan agar dapat mengetahui suatu fenomena sosial termasuk didalamnya adalah terkait fenomena pendidikan. Teknik pelaksanaan yang digunakan dalam kegiatan pengabdian yaitu observasi, wawancara dan praktik langsung untuk melibatkan masyarakat di Desa Astapada.

Pelaksanaan wawancara dan observasi yang dilakukan adalah untuk meminta izin ke RT untuk melakukan kegiatan pengabdian sekaligus melakukan observasi pendahuluan untuk mengetahui kondisi masyarakat. Setelah itu, penulis kemudian silaturahmi dan berkenalan dengan Kepala Desa serta perangkat Desa lainnya, untuk melakukan wawancara secara mendalam terkait pengetahuan mengenai kondisi masyarakat Desa Astapada dari mulai sejarah, sektor ekonomi, kemasyarakatannya dan sampai ke berbagai data penduduk Desa Astapada. Tidak lupa, penulis juga melakukan silaturahmi kepada paratokoh masyarakat di desa setempat. Setelah itu, penulis juga melakukan pendekatan kepada anak-anak muda yaitu melakukan pendekatan sosial pendidikan sekaligus melakukan upaya preventif untuk mengajak para pemuda aktif berpartisi dalam penyelesaian program pegabdian ini.

Dalam melakukan pendampingan pembelajaran dari rumah dengan tetap menerapkan protokol kesehatan, penulis menggunakan metode Belajar Bersama di rumah belajar, yaitu 
pembelajaran dengan berkelompok anak. Metode ini dipilih karena dengan melakukan kegiatan belajar bersama anak lebih mudah memahami apa yang akan dilakukan untuk tugasnya bersama dengan teman-temannya. Dalam melakukan evaluasi hasil dari pendampingan pembelajaran, penulis menggunakan metode observasi atau wawancara langsung dengan masyarakat terutama anak-anak usia sekolah yang mengikuti belajar bersama di rumah belajar.

\section{HASIL DAN PEMBAHASAN}

Dalam pelaksanaan program (pendidikan masyarakat), penulis mengupayakan untuk memberdayakan masyarakat melalui pembinaan dan pendampingan anak-anak sekolah di desa Astapada. Adapun secara rinci pelaksanaan kegiatan pengabdian ini penulis uraikan sebagaimana berikut :

\section{Masyarakat Belajar (Learning Community)}

Masyarakat Belajar (Learning Community) secara konseptual, diawali oleh pembentukan individu-individu yang menjadi warganya. Pengubahan individu yang santai menjadi individuyang gesit dan bekerja keras, individu yang konsumtif menjadi individu yang produktif, individu penerima menjadi individu pemberi, individu yang mudah menyerah pada keadaan menjadi individu yang gigih mengubah keadaan, menuntut perubahan mendasar pada pribadi individu-individu tersebut. Perubahan tersebut diawali pada perubahan persepsi dan sikap, baik terhadap dirinya, maupun terhadap lingkungan, peluang-peluang, ancaman dan hambatan yang dihadapi. Kemudian dilanjutkan dengan menumbuhkan kepercayaan diri, dan motivasi untuk maju. Setelah ada kepercayaan diri, bahwa dirinya memiliki kekuatan, potensi dan kemampuan, tumbuh motivasi untuk berubah, mau belajar, mau berusaha, maka kegiatan belajar bisa dimulai (Sukmadinata, 2005).

Itu artinya bahwa jika suatu bangsa/suatu negara sudah tumbuh kesadaran dan berkemauan untuk belajarnya semakin tiunggi, maka bangsa/negara itu sudah mulai muncul masyarakat belajar. Dalam masyarakat belajar, yang melakukan perbuatan belajar tidak hanya anak-anak dan remaja, tetapi juga orang dewasa melakukan usaha belajar hingga sepanjang hayatnya.

Hanya saja perlu dipertegas bahwa dimaksud belajar tidak hanya interaksi sosial di sekolah (pendidikan formal), tetapi belajar juga berlanngsung di lingkup yang lebih luas. Seseorang bisa belajar tentang sesuatu melalui berbagai cara, misalnya melalui pengalaman praktik di tempat kerjanya (best practice), belajar dari orang lain, belajar dari ahli, dan belajar dari berbagai sumber lainnya, yang intinya berusaha untuk memperbaiki dan meningkatkan pengetahuan dan keterampilan. Demikian pula, belajar ekonomi, ketika akan menjadi penting saat dihadapkan 
dengan masalah kenaikan sembako atau BBM, dia mungkin bisa berfikir, bersikap dan berbuat apa yang seharusnya agar dia tidak menjadi korban dari kenaikan sembako atau BBM tersebut.

Semakin banyak individu atau anggota masyarakat yang melakukan perbuatan belajar, maka niscaya akan semakin baik pula kehidupan bangsa dan negara ini, yang pada akhirnya dapat mengantarkan kita semua benar-benar menjadi sebuah bangsa yang maju, sejatera dan terhormat

Karena itu Learning Community dapat dilaksanakan dengan memperhatikan hal-hal sebagai beerikut: yaitu: Sekelompok orang yang terikat dalam kegiatan belajar, Bekerjasama dengan orang lain lebih baik daripada belajar sendiri, bertukar pengalaman, berbagi ide, berbicara dan berbagi pengalaman dengan orang lain, Ada kerjasama untuk memecahkan masalah, Hasil pembelajaran secara kelompok akan lebih baik daripada belajar sendiri dan ada fasilitator/guru yang memandu proses belajar dalam kelompok.

\section{Rumah Belajar}

Perkembangan teknologi membuat orangtua/masyarakat memiliki banyak pilihan dalam mendampingi anak-anaknya selama belajar di rumah. Beberapa tahun ini, Kementerian Pendidikan dan Kebudayaan (Kemdikbud) nmeluncurkan salah satu aplikasi yang dapat dimanfaatkan adalah 'Rumah Belajar'. Karena itu rumah belajar merupakan portal gratis yang disediakan oleh pemerintah sebagai inovasi pembelajaran di era industri 4.0 alias pembelajaran online yang dapat dimanfaatkan oleh siswa maupun guru. Prinsip rumah belajar adalah memberikan kesempatan pada anak-anak untuk belajar di mana saja, kapan saja, dan dengan siapa saja. Materi pembelajaran yang disediakan dapat digunakan oleh siswa/guru pendidikan PAUD, SD, SMP hingga SMA/MA/SMK. Bukan hanya dalam bentuk teks, konten pembelajaran juga tesedia dalam bentuk gambar, animasi, video dan simulasi, serta buku digital.

Namun, Rumah Belajar yang dimaksud dalam tulisan ini yaitu suatu bentuk kegiatan pembelajaran bagi masyarakat yang dilaksanakan setisp hari Sabtu dan Ahad, dimana anak-anak bisa belajar, membaca, berkreasi dan bermain bertempat di salah satu tempat tinggal (rumah) masyarakat. Rumah Belajar ini fungsinya seperti rumah singgah, siapapun anak-anak yang ingin belajar baca, menulis, mewarnai bisa mendatangi rumah belajar. Di Rumah Belajar juga, anakanak di dampingi mengerjakan Pekerjaan Rumah (PR) dan belajar berkreasi dengan membuat kreasi tangan dari kertas origami, disitu kami belajar bersama dari membuat bunga, dan kupukupu (bross dan gantungan dari kain flanel). 


\section{Kegiatan Sosial}

Kegiatan sosial pendidikan ditujukan sebagai upaya tambahan belajar bagi anak-anak atau femaja usia sekolah, agar mereka lebih menumbuhkan rasa sosial terhadap sesama. Kegiatan sosial pendidikan, dimulai dari yang terkecil yaitu di lingkungan anak-anak bermain, dimana anak-anak bisa membantu teman-temannya yang sedang kesusahan. Selain itu juga anak-anak diajarkan untung saling gotong royong seperti pada hari jumat melaksanakan kerja bakti membersihkan lingkungan, apa lagi pada saat seperti ini kita harus menjaga kebersihan lingkungan.

Pendampingan dilakukan kepada aparat desa dalam menyelesaikan tugasnya yaitu pembagian Bantuan Langhsung Tunai (BLT) terhadap masyarakat, yaitu mendata masyarakat yang mendapatkan bantuan, serta berpartisipasi dalam pemberian bantuan dari Dinas Sosial Kabupaten Cirebon kepada lansia. Kegiatan sosial pendidikan dilakukan juga dalam bentuk bakti sosial bersama-sama dengan masyarakat yaitu melakukan pemeriksaan kesehatan gratis bekerja sama dengan Puskeesmas, makanan gratis bekerja sama dengan para dermawan dan terapi gratis bahkan pemberian bekal mengenai pembuatan sari jahe murni.

Dalam melaksanakan kegiatan sosial pendidikan, penulis menggunakan pendekatan partisipatory masyarakat, dimulai dari perencanaan, pelaksanaan, monitoring dan evaluasi. Disampaikan secara terbuka kepada anak-anak agar mendapatkan dukungan dari anak-anak.

\section{Kegiatan Kependidikan}

Kegiatan kependidikan, meliputi pembelajaran dan permainan yang dilaksanakan di suatu tempat apayang disebut Rumah Belajar. Rumah Belajar yang berfungsi sebagai tempat bermain sambil belajar, layaknya Rumah Singgah. Di Rumah Belajar/Rumah Singgah itu diisi berbagai kegiatan pembelajaran bagi anak-anak di saat pandemi ini yang seharusnya dilakukan di lembaga pendidikan, mendampingi dan/atau membantu anak-anak dalam mengerjakan pekerjaan rumah dari sekolahnya.

Disampaikan juga bahwa model dan metode belajar dilakukan. Di antara metode yang digunakan adalah Learning by playing, Cooperartif type Learnng together, Mmetode Iqra, Metode hafalan dan Ceramah dan praktek

1. Learning by playing, yaitu belajar sambil bermain.

2. Cooperatif type learning together yaitu melakukan kegiatan pembelajaran (Pukul 15:00 s.d 17:45) dan melakukan persiapannya terlebih dahulu seperti berdoa sebelum memulai mengaji kemudian pengajaran tentang materi makhorijul huruf dengan menggunakan metode kerjasama (cooperatif), yaitu setelah dijelaskana dan menghafal anak-anak dibagi jadi 
beberapa kelompok dan berdiskusi mengenai jawabannya setelah itu anak-anak harus menjawab secara bersamaan dan harus kompak.

3. Metode Iqra yaitu melakukan pengajaran al-Quran terhadap anak-anak yang belajar al-Quran dengan meggunakan metode iqro mengenai tata cara wudhu, huruf hijaiyyah, anggota tubuh dalam bahasa arab, nama-nama Nabi dan sifat-sifat wajib bagi Allah. Karena ketika belajar dengan anak-anak ini, mereka harus semangat dan bersenang senang maka dari itu saya menggunakan model pembelajaran dengan bernyanyi agar anak-anak cepet tanggap dan selalu keinget. Contohnya saja tata cara wudhu di jadikan nyanyian dengan judul tepuk wudhu.

4. Metode hafalan, yaitu dalam pembelajaran di Rumah Belajar/rumah singgah digunakan juga metode hafalan terutama pada surat-surat pendek, doa-doa shalat dan doa-doa sehari-hari, dimana setelah anak-anak melakukan mengaji, mereka diminta untuk menghafal juz amma, yang pertama anak-anak melihat atau membaca surat terlebih dahulu secara berulang-ulang kemudian setelah lancar dan hafal juz amma pun di tutup dan setoran tanpa melihat bacaan suratnya. Dan diulang berkali-kali sampai sianak itu bener-bener hafal. Baik dalam menghafal surat juz amma maupun doa-doa sehari-hari.

5. Ceramah dan praktek, yaitu mengajar diawali dengan penjelasan terlebih dahulu dan setelah itu kita mempraktekkan baru kemudian anak-anak pun mempraktekkannya. Dimulai dengan menjelaskan tentang hukum mad, sholat, bacaan basmalah dan $t a$ 'awudz yang benar.

Adapun model yang digunakan adalah Snawball Throwing, Model Team Games Tournament (TGT), Model Make a Match

1. Snawball Throwing, yaitu suatu model pembelajaran yang sdebelim pembelajran dimulai, terlebih dahulu guru menjelaskan materi tentang makhorijul huruf dan mengenai covid-19; setelah itu anak-anak dibagi kedalam beberapa kelompok. Setiap kelompok menyiapkan salah satu dari mereka menjadi ketua dari kelompoknya masing-masing, setelah menentukan ketua kelompok, guru memanggil dari setiap ketua kelompoknya untuk diberi ulang materi arahan dalam memulai model pembelajaran ini, dimana dari setiap kelompok memebuat suatu pertanyaan mengenai kedua materi dan setelah itu dikumpulkan di guru dalam bentuk bulatan kertas seperti bola salju. Kemudian dari masing-masing kelompok melemparkan pertanyaan ke kelompok lain sampai semua pertanyaan tercampur. Setelah itu dari setiap kelompok menjawab pertanyaan yang mereka dapat dan nanti guru akan merefleksi kegiatan pembelajaran

2. Model Team Games Tournament (TGT). Pengajaran dengan cara menjelaskan sifat huruf yang tidak berlawanan kemudian menggunakan sebuah metode pembelajaran yaitu metode 
TGT dan berkreasi secara kelompok. Model ini adalah salah satu pembelajaran kooperatif dimana anak-anak diharuskan kompak dengan kelompok karena model ini guru menyiapkan berbagai pertanyaan di kertas karton lalu karton tersebut di tempel di papan tulis dan dari setiap kelompok itu berbaris kebelakang untuk bergantian menjawab pertanyaan yang sudah disediakan, di sini anak-anak dilatih kerjasama, teliti, jujur dan kreatif. Diberi waktu untuk mengerjakan dan setelah selesai mengerjakan jawaban tersebut akan dikoreksi oleh guru siapakah yang benar semua dan ketika ada salah akan di benarkan. Setelah itu anak-anak berkreasikan kertas karton tersebut dengan berbagai gambar atau pun hiasan lainnya.

3. Model Make a Match, yaitu mengajarkan tentang sejarah Qorun orang kaya yang takabur dengan menggunakan metode make a match dimana ana-anak menonton filmnya qorun terlebih dahulu lalu diinget dan di pahami setelah itu anak-anak boleh memilih kertas yang di dalamnya sudah ada pertanyaan dan jawaban jadi anak-anak harus menjodohkan antara pertanyaan dan jawaban yang benar. Setelah menemukan hasilnya maka mereka sudah menemukan jodoh dari pertanyaan dan jawabannya.

Kegiatan pendampingan belajar di rumah belajar, dilakukan selama 20 hari dan 4 hari. Penulis melakukan pengamatan dan penilaian juga wawancara mendalam. Kegiatan lain selain pendampingan pembelajaran, juga dilakukan beberapa kegiatan penunjang selama 3 hari, yakni dengan kegiatan pembuatan profil lembaga, pembuatan dan pembagian handsanitizer kepada masyarakat bekerja sama dengan intansi kesehatan.

\section{KESIMPULAN}

Hasil dari pengabdian dalam bidang pendidikan adalah 1) Mendapatkan banyak dukungan dari warga maupun pihak desa tentang adanya pengadaan sarana belajar selama pandemi ini. 2) Banyak anak-anak yang menghabiskan waktunya untuk belajar bersama dibandingkan dengan bermain, 3) Anak-anak dapat mengelola barang bekas seperti plastik menjadi bahan yang lebih bermanfaat. 4) Anak-anak dapat menambah rasa percaya diri dengan berani menceritakan pengalamannya di depan teman-temannya. Suatu tuntutan dan kewajiban bagi pendidik yaitu harus mampu menggunakan berbagai model atau metode pembelajaran agar peserta didik dapat melakukan kegiatan belajar dengan maksimal, dan hasil yang dicapai pun dapat memuaskan. Dan juga bertujuan agar murid dapat lebih cepat menangkap dan mengingat mata pelajaran yang diberikan oleh guru. 


\section{UCAPAN TERIMA KASIH}

Terima kasih disampaikan kepada seluruh unsur masyarakat di Desa Astanapada, Kabupaten Cirebon yang telah memberikan kesempatan dan banyak mendukung kegiatan penulis sehingga program pengabdian ini dapat berjalan dengan lancar.

\section{DAFTAR PUSTAKA}

Annisa, Aulia. Tantangan. (2021, January 19). Guru Dalam Proses Pembelajaran Daring Di Masa Pandemi Covid-19. https://doi.org/10.31219/osf.io/btj7m

Arizona, K., Abidin, Z., \& Rumansyah, R. (2020). Pembelajaran Online Berbasis Proyek Salah Satu Solusi Kegiatan Belajar Mengajar di Tengah Pandemi Covid-19. Jurnal Ilmiah Profesi Pendidikan, 5(1), 64-70

Arsyad, Azhar. 2011. Media Pembelajaran. Jakarta: PT. Raja Grafindo Persada

Bakhri, S., Herawati, C., \& Nuroniyah, W. (2020). Prospek dan tantangan kabupaten layak anak (KLA) di kabupaten Cirebon. Yinyang: Jurnal Studi Islam Gender Dan Anak, 15(2), 225244. https://doi.org/https://doi.org/10.24090/yinyang.v15i2.3782

Dani, Awis Hamid., et al. (2021). Kondisi Ekonomi, Stigma, Dan Tingkat Religiusitas Sebagai Faktor Dalam Meningkatkan Upaya Pencegahan Covid-19. Jurnal Kedokteran dan Kesehatan, 8(2), 75-86. https://ejournal.unsri.ac.id/index.php/jkk/article/view/13306/0

Herawati, Nenden Ineu. (2010). Pendidikan Inklusif. Jurnal EduHumaniora: Jurnal Pendidikan Dasar, 2(1).

Ilmy, N. A.. (2014). Pengaruh Pembelajaran Direct Instruction dengan Suplemen Rumah Belajar (Situs E-Learning Kemdikbud) terhadap Hasil Belajar Siswa pada Materi Sistem Saraf Manusia, Jakarta

Kementerian Pendidikan dan Kebudayaan. (2012). Standar dan prosedur Penyelenggaraan Pusat Kegiatan Belajar Masyarakat (PKBM). Jakarta: Kementerian Pendidikan dan Kebudayaan Layaman., Nasichah. Nur Aulia., \& Hanim, Tika Fatichah. (2020). Pemberdayaan Remaja Melalui Budidaya Tanaman Hidroponik Kampung Kertasemboja, Kelurahan Pegambiran, Kota Cirebon. Dimasejati 2(2), 191-203.

Majid, et al. (2021). Optimalisasi Pembelajaran Efektif di Rumah Saat Pandemi Covid-19 Kepada Warga Persyarikatan Muhammadiyah Kabupaten Purwakarta. Indonesian Journal of Community Services in Engineering \& Education (IJOCSEE), 1(1). 1-7.

Majid, N. W. A. (2013). The Effect of Industrial Practice of Experience And Competence of ICT on Job Readiness of 12th Class SMK Negeri 3 Yogyakarta Academic Year 2012/2013. Fakultas Teknik, Universitas Negeri Yogyakarta. 
Mardikanto, T.,\& Soebiato, P. (2013). Pemberdayaan Masyarakat dalam Perspektif Kebijakan Publik. Bandung: Alfabeta.

Nurhayati, A. S. (2012). Pedoman Pemanfaatan Rumah Belajar, Jakarta: Pustekkom Kemdikbud

Putri, W. (2021). E-Learning Pedagogical Challenges of EFL Teachers During COVID-19 $\begin{array}{llll}\text { Pandemic. } & \text { Journal }\end{array}$ https://ejournal.upi.edu/index.php/edutech/article/view/30993

Sarip, et al. (2020). Dampak Covid-19 Terhadap Perekonomian Masyarakat dan Pembangunan Desa. Jurnal Al-Mustashfa, 5(1), 10-20. https://syekhnurjati.ac.id/jurnal/index.php/almustashfa/article/view/6732/3120

Sukmadinata, Nana Syaodih (2005). Landasan Psikologi Proses Pendidikan. Bandung: PT Rosda Karya.

UU RI Nomor 20 tahun 2003 tentang Sustem Pendidikan Nasional

Vito, Benediktus., Krisnani, Hetty \& Resnawaty, Risna. (2015). Kesenjangan Pendidikan Desa Dan Kota. PROSIDING KS: RISET \& PKM, 2(2). 147-300.

Winarno., Setiawan, Johan. (2013). Penerapan Sistem E-Learning pada Komunitas Pendidikan Sekolah Rumah (Home Schooling). ULTIMA InfoSys, 4(1). 